\title{
Heavy Metal Levels in Soil, Tomatoes and Selected Vegetables from Morogoro Region, Tanzania
}

\author{
Lugwisha Esther Hellen*, Othman Chande Othman \\ Chemistry Department, University of Dar es Salaam, Dar es Salaam, Tanzania \\ Email address: \\ elugwisha@gmail.com (Lugwisha E. H.), o_chande@yahoo.co.uk (Othman O. C.) \\ *Corresponding author
}

\section{To cite this article:}

Lugwisha Esther Hellen, Othman Chande Othman. Heavy Metal Levels in Soil, Tomatoes and Selected Vegetables from Morogoro Region, Tanzania. International Journal of Environmental Monitoring and Analysis. Vol. 4, No. 3, 2016, pp. 82-88. doi: 10.11648/j.ijema.20160403.13

Received: March 18, 2016; Accepted: March 28, 2016; Published: April 20, 2016

\begin{abstract}
The concentrations of heavy metals of $\mathrm{Cd}, \mathrm{Cu}, \mathrm{Cr}, \mathrm{Pb}$ and $\mathrm{Zn}$ were determined in cauliflower (Brassica oleracea L. var. butrytis L.), carrot root (Daucus carota L.), tomato fruit (Lycopersicon esculenta Mill.), onion bulb (Allium cepa L.) and leafy cabbage (Brassica oleracea var. capital capitata L.), and the respective soils from Morogoro region, Tanzania. The accumulated heavy metals were quantified and levels compared to FAO/WHO (2003) and TZS (2007) safety limits for such produce. The methodology involved random sampling, extraction of the metals from the tomatoes, vegetables and soil and determination of heavy metals by using ICP-OEC and GFAAS. The results showed that levels of $\mathrm{Cd}, \mathrm{Cu}, \mathrm{Cr}, \mathrm{Pb}$ and $\mathrm{Zn}$ at $90 \%$ of the sites in vegetables and tomatoes were above the FAO/WHO limit. The mean concentrations of $\mathrm{Cd}, \mathrm{Cr}, \mathrm{Pb}$ and $\mathrm{Zn}$ in all vegetables and tomatoes except $\mathrm{Cu}$ were also found to be above this limit therefore advocating a health risk for consumers. Levels of heavy metals in the soils were below the limits of the Tanzanian standard (TZS 972: 2007) and were lower than levels found in vegetables. The bioconcentration factor for $\mathrm{Cu}$ recorded 1 for tomatoes and cabbage at Towelo and below 1 for tomatoes and cauliflowers from Mgeta. Cd in onions at Mgeta as well recorded below 1. However, the bioconcentration factor for these heavy metals in vegetables and tomatoes in all other sites were found to be above 1 in all heavy metals an indication of high uptake of heavy metals in the vegetables and tomatoes from the soil. These results suggest that such vegetables and tomatoes might place the consumers at health risk; therefore they are not safe for consumption in their raw state.
\end{abstract}

Keywords: Heavy Metals, Vegetables, Tomatoes, Soil, Bioconcentration Factor, Tanzania

\section{Introduction}

Heavy metals are found naturally in the earth, and become concentrated as a result of human activities such as industrial production, mining, agriculture and transportation [1,2]. These metals have both positive and negative roles in human life [1-4]. For instance, heavy metals such as copper $(\mathrm{Cu})$, chromium $(\mathrm{Cr})$, cobalt $(\mathrm{Co})$, manganese $(\mathrm{Mn})$ and zinc $(\mathrm{Zn})$ are essential micronutrients for higher animals and for plant growth [5]. However, at higher concentrations they can lead to poisoning. On the other hand, Lead $(\mathrm{Pb})$, cadmium $(\mathrm{Cd})$, Arsenic (As) and nickel (Ni) are significant environmental pollutants [6]. Studies have revealed that fruits and leafy vegetables are vulnerable to heavy metal contamination from soil, wastewater and air pollution [7]. Heavy metals such as $\mathrm{Cd}$, $\mathrm{Cu}, \mathrm{Pb}, \mathrm{Cr}, \mathrm{Zn}, \mathrm{Ni}, \mathrm{As}$, $\mathrm{Co}$ and $\mathrm{Hg}$ cannot be degraded or destroyed and can be accumulated in living tissues through the food chain, causing various diseases and disorders [7]. This fact necessitates for frequent determination of heavy metals in fruits, vegetables and soil to ensure that their levels meet the agreed international standards for the safety of consumers. Fruits, vegetables and other foods are among pathways by which heavy metals enter the human tissues leading to deterioration of health [8]. Tanzania has several regions where fruits, vegetables and other horticultural products are grown. These regions among others include Lushoto, Iringa, Mbeya, Morogoro, Kilimanjaro and Arusha [9, 10]. Morogoro Region is well known for the growing of tomatoes and green vegetables throughout the year. These fruits and vegetables are sold through different chains of markets, from local villages, regional to national markets and supermarkets while others are exported to neighboring countries [10].

Several studies conducted in Tanzania, on heavy metals in 
fruits, vegetables and soils have indicated the presence of heavy metal contamination at different concentrations [11-15]. A similar study was conducted in Morogoro for pumpkin and chinese cabbage by Chove et al. [16]. Lugwisha and Othman [17] studied the contents of heavy metals in tomato fruits, vegetables and respective soil in Lushoto district and found that the vegetables and fruits were not safe for consumption. Determination of heavy metals in edible portions of amaranth (Amaranthus viridis), chinese cabbage (Brassica chinensis), cowpea leaves (Vigna unguiculata), leafy cabbage (Brassica oleracea var. capitata) and pumpkin leaves (Cucurbita moschata) in Dar es Salaam has shown the presence of Cd, Ni, $\mathrm{Pb}, \mathrm{Cr}, \mathrm{Cu}$ and $\mathrm{Zn}$ [18]. A direct correlation between $\mathrm{Zn}$ and $\mathrm{Pb}$ levels in soils with the levels in vegetables was also observed [12]. Consuming such vegetables may lead to severe health problems, such as acute/chronic chemical poisoning of body tissues. Knowledge of the contamination of soil, fruits and vegetables with heavy metals from some areas in Morogoro region, Tanzania has not yet been established; therefore, the present study was undertaken with the aim to investigate the concentration of some specific heavy metals $(\mathrm{Cd}, \mathrm{Cu}, \mathrm{Cr}, \mathrm{Pb}$ and $\mathrm{Zn}$ ) in cauliflower (Brassica oleracea var. botrytis L.), onion bulb (Allium cepa L.) carrot root (Daucus carota L.), leafy cabbage (Brassica oleracea var. capitata L.), tomato fruits (Lycopersicum esculentum Mill.), and the respective soils from this region.

\section{Material and Methods}

Samples of tomatoes, cauliflowers, cabbages, carrots and onions and of their respective soils were collected from 9 different locations (Table 1) in Morogoro region. About two kilograms of each sample of tomatoes and vegetables were randomly collected at each site, wrapped in pre-cleaned aluminum foil, packed in polyethylene bags and transported to Chemistry Department, University of Dar es Salaam for pre-treatment. Simultaneously, soil was sampled from the same locations of vegetables and tomatoes collection from a depth of 2 to $15 \mathrm{~cm}$ by using a non-steel sampler (scoop sampling). Samples were stored in sealed pre-cleaned polyethylene bags and transported to the Chemistry Department for investigation.

Table 1. Locations, soil pH and samples from Morogoro Region, Tanzania.

\begin{tabular}{|c|c|c|c|}
\hline Location & Soil pH & Sample name & Scientific name \\
\hline Kihonda & 7.22 & Onion & Allium cepa $\mathrm{L}$. \\
\hline Mgeta & 5.84 & Tomatoes & Lycopersicon esculenta Mill. \\
\hline Mgeta & 6.30 & Cabbages & $\begin{array}{l}\text { Brassica oleracea var. } \\
\text { capital capitata } \mathrm{L}\end{array}$ \\
\hline Mgeta & 5.56 & Cauliflower & $\begin{array}{l}\text { Brassica oleracea L. var. } \\
\text { butrytis L. }\end{array}$ \\
\hline *Mgeta sokoni & NA & Onion & Allium cepa $\mathrm{L}$. \\
\hline *Mgeta sokoni & NA & Tomatoes & Lycopersicon esculenta Mill. \\
\hline Towelo & 6.13 & Tomatoes & Lycopersicon esculenta Mill. \\
\hline Towelo & 5.53 & Carrots & Daucus carota $\mathrm{L}$. \\
\hline Towelo * & 6.13 & Cabbages & $\begin{array}{l}\text { Brassica oleracea var. } \\
\text { capital capitata } \mathrm{L} .\end{array}$ \\
\hline
\end{tabular}

*Soil sample was not collected as samples were collected from the market

\subsection{Sample Preparation}

\subsubsection{Vegetable and Tomato Samples}

Chove et al. [16] method which was followed with minor modifications was used for vegetable and tomato samples collection. The collected samples were first washed with tap water and rinsed three times with distilled water to remove surface pollutants and any items adhering to the surfaces. The washed samples were sliced into small pieces and dried in open air on paper for about 2 hours to eliminate excess moisture. Each sample was weighed, dried in an oven at $80^{\circ} \mathrm{C}$ for several hours and reweighed to constant weight. The dried sample was then ground in a mortar until it could pass through a $2 \mathrm{~mm}$ mesh sieve and stored in clean and dry polyethylene bags.

\subsubsection{Soil Sample Extracts}

Larger particles and other debris were removed from the soil samples. The samples were then air dried, ground, and sieved. Approximately $5.0 \mathrm{~g}$ samples were weighed by using a digital weighing balance and placed in a flask. $20 \mathrm{~mL}$ of extracting acid solution $\left(0.05 \mathrm{~N} \mathrm{HCl}+0.025 \mathrm{~N} \mathrm{H}_{2} \mathrm{SO}_{4}\right)$ were added to the samples and shaken vigorously by a mechanical shaker for 15 minutes. The solution was then filtered through a Whatman filter paper No.42 into a $50 \mathrm{~mL}$ volumetric flask and diluted to the mark prior to analysis of soil parameters.

\subsubsection{Sample Digestion - Dry Ashing}

About $2 \mathrm{~g}$ of ground tomatoes and vegetables were placed in a clean porcelain crucible and kept in a cool muffle furnace. The sample was then ashed at $450-500^{\circ} \mathrm{C}$ overnight $(12$ hours). The ashed sample was cooled to room temperature in a desiccator. The ash was then dissolved in $5 \mathrm{~mL}$ of $20 \%(\mathrm{v} / \mathrm{v})$ hydrochloric acid. The solution was warmed slowly to dissolve any residues. The solution was filtered through an acid-washed Whatman filter paper No 42 into a $50 \mathrm{~mL}$ volumetric flask. The filter paper was washed with distilled water and washings collected in the volumetric flask. The resulting solution was diluted to the mark with distilled water, well mixed and used for determination of the heavy metals in vegetable samples [12].

\subsection{Determination of Soil pH}

The soil $\mathrm{pH}$ was determined by the use of $\mathrm{pH}$-meter (RS Components Ltd, stock No 610-540, serial No.082316, UK) with a combined glass electrode. The $\mathrm{pH}$ meter was calibrated over the proper range using standard buffer solutions of $\mathrm{pH} 4$ and $\mathrm{pH} 7$. Adjustment was done for temperature and potential required by the instrument.

About $5 \mathrm{~g}$ of each soil samples were accurately weighed using the digital weighing balance (Mettler Toledo model B 301-S) and sieved. $50 \mathrm{~mL}$ distilled water was added to the sample [19]. The mixture was stirred vigorously for 15 seconds in a mechanical shaker and left to stand for 30 minutes. The electrode removed from the buffer solution was rinsed in the sample, placed in the slurry and swirled carefully. The $\mathrm{pH}$ values were recorded after each reading had stabilized. The electrode was always rinsed with distilled water between successive measurements. 


\subsection{Determination of Heavy Metals}

Determination of heavy metals from the filtrate of tomatoes, vegetables and soil samples were carried out by using the GFAAS (Analytik Jena AG/Konrad-Zuse-Straße 1/07745/Germany) for $\mathrm{Cu}$ and ICP-OES (Ultma2, HORIBA Jobin Yvon S.A.S, version 3, 2001, France) for $\mathrm{Cd}, \mathrm{Cr}, \mathrm{Pb}$ and $\mathrm{Zn}$. The analytical procedure is as described in [12].

\subsection{Quality Assurance}

Quality control tests were conducted on soil, tomatoes and vegetable samples in order to evaluate the experimental procedures and efficiency of the GFAAS and ICP-OES methods. The quality assurances was done by spiking each of the pre-digested samples of vegetable and soil with diluted solution of heavy metals standard solution $(20 \mu \mathrm{g} / \mathrm{kg}$ of Cd, $\mathrm{Cr}$, $\mathrm{C}, \mathrm{Pb}$, and $\mathrm{Zn}$ ) prepared from several dilution of the $1000 \mu \mathrm{g} / \mathrm{g}$ stock standard solution. The spiked samples were then digested and extracted using the same procedure as that of soil and vegetable samples.

\subsection{Statistical Analysis}

Unpaired student's t-test was used to determine and compare the statistical differences between the mean concentrations of two groups of samples. A probability level of $\mathrm{P}<0.05$ was considered statistically significant. The analysis was performed by feeding the raw data into a special program for unpaired student's t-test determination as described by Kothari [20].

\subsection{Bioconcentration Factor $(B C F)$}

The transfer of trace elements from soil to plant edible parts is best described by considering the bioconcentration factor. $\mathrm{BCF}$ is calculated as the ratio of the concentration of heavy metals in the vegetables to that in the corresponding soil where vegetables were obtained, all based on (dry weight) for each vegetable separately.

The bioconcentration factor $=[\mathrm{M}]$ plant $/[\mathrm{M}]$ soil where $[\mathrm{M}]$ plant and [M] soil represent the heavy metal concentration in extracts of plants and soils on a dry weight basis respectively

\section{Results and Discussion}

\subsection{Soil pH}

The $\mathrm{pH}$ of the soils from the investigated locations (Table 1) ranged between mildly acidic $(\mathrm{pH}$ 5.53) at Towelo to moderately alkaline $(\mathrm{pH} 7.22)$ at Kihonda, with a mean of $\mathrm{pH}$ $6.06 \pm 0.60$ (i.e. $6.06 \pm$ Std Deviation). Akinola et al. [19] conducted a study in a non-industrial area and recorded $\mathrm{pH}$ 6.02 . He concluded that $\mathrm{pH}$ recorded near neutral cause low uptake of heavy metals by vegetables, thereby leaving a higher concentration in the soil. In our study, in soil where $\mathrm{pH}$ was recorded near neutral (7.22), low concentrations of heavy metals were recorded in the soil contrary to [19]. This might be due to vegetables and tomatoes absorbing heavy metals through leaves exposed to air from polluted environment [16].

\subsection{Concentrations of Heavy Metals in Vegetables, Tomatoes and Soils}

\subsubsection{Cadmium}

Cadmium (Cd) is one of the most toxic heavy metals, because it bioaccumulates and has a long half life of about 30 years thereby causing health disorders such as lung cancer, kidney damage (necrotic protein precipitation), metabolic anomalies caused by enzyme inhibitions, reproductive failure, damage of central nervous system and DNA [21, 22, 24].

The concentrations of $\mathrm{Cd}$ in tomatoes, vegetables and soils at different sites of Morogoro are presented in Fig. 1. The concentrations of $\mathrm{Cd}$ in tomatoes and vegetables were recorded below detection limit in all samples except in onions from Mgeta sokoni $(0.09 \mu \mathrm{g} / \mathrm{g}-\mathrm{dw})$ and in cabbages from Towelo $(0.14 \mu \mathrm{g} / \mathrm{g}-\mathrm{dw})$, both values being above the FAO/WHO [23] permissible limit of $0.05 \mu \mathrm{g} / \mathrm{g}$. At Towelo (cabbage), the soil recorded the $\mathrm{pH}$ of 6.13 which meant the soil was slightly acidic, thus facilitating solubility and availability of Cd for vegetable uptake [19]. The Cd uptake by vegetables from soil is greater at low $\mathrm{pH}$ of soil [19, 23].

In the respective soils, $\mathrm{Cd}$ was recorded below detection limit in all samples except in tomatoes $(0.02 \mu \mathrm{g} / \mathrm{g}-\mathrm{dw})$ and cabbage $(0.03 \mu \mathrm{g} / \mathrm{g}-\mathrm{dw})$ at Mgeta with $\mathrm{pHs} 5.84$ and 6.30 (slightly acidic), respectively, both being recorded below the TZS [25] permissible limit of $1.0 \mu \mathrm{g} / \mathrm{g}$.

Similar to the present study, studies [21, 26, 27] also recorded the concentration of $\mathrm{Cd}$ at below the $\mathrm{FAO} / \mathrm{WHO}$ permissible limit in cauliflowers, cabbages, onions and tomatoes. On the other hand, Ray et al. [28] conducted studies in non-polluted areas and recorded high concentrations of $\mathrm{Cd}$ $(1.1 \mu \mathrm{g} / \mathrm{g}-\mathrm{dw})$ in cauliflower, cabbage and tomatoes, than in their respective soils $(0.014 \mu \mathrm{g} / \mathrm{g}$-dw to $0.721 \mu \mathrm{g} / \mathrm{g}-\mathrm{dw})$.

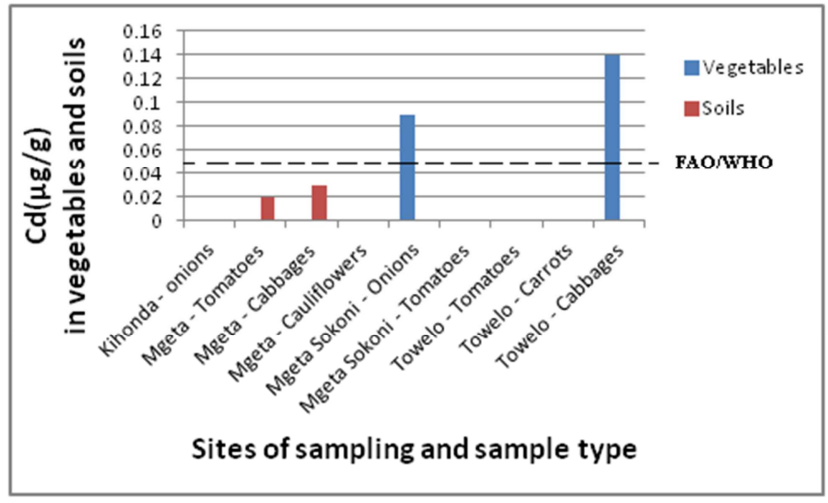

Figure 1. Cadmium levels in vegetables and soils from Morogoro.

\subsubsection{Copper}

Copper is an essential micronutrient element, which functions as a biocatalysts, required for body pigmentation, maintain a healthy central nervous system, prevents anemia and interrelated with the function of $\mathrm{Zn}$ and iron in the body [29]. The FAO/WHO [30] acceptable limit of $\mathrm{Cu}$ for human consumption in vegetables is $(5 \mu \mathrm{g} / \mathrm{g})$. When copper exceeds its safe concentration, it causes hypertension, sporadic fever 
and coma.

In this study the concentration of $\mathrm{Cu}$ varied between $(0.06$ $\mu \mathrm{g} / \mathrm{g}-\mathrm{dw})$ in cauliflowers at Mgeta and $(7.19 \mu \mathrm{g} / \mathrm{g}-\mathrm{dw})$ in onions at Kihonda (Fig. 2). The concentrations of $\mathrm{Cu}$ in vegetables and tomatoes were recorded below the FAO/WHO [30] permissible limit of $5 \mu \mathrm{g} / \mathrm{g}$. except in onions at Kihonda (7.19 $\mu \mathrm{g} / \mathrm{g}-\mathrm{dw})$ and carrots at Towelo $(6.11 \mu \mathrm{g} / \mathrm{g}-\mathrm{dw})$. The mean concentration of $\mathrm{Cu}$ in vegetables and tomatoes was $1.80 \pm 2.80 \mu \mathrm{g} / \mathrm{g}$-dw. The level of $\mathrm{Cu}$ was high in vegetables and tomatoes compared to soil, indicating uptake to vegetables.

The results of $\mathrm{Cu}(7.19 \mu \mathrm{g} / \mathrm{g}-\mathrm{dw})$ in onion at Kihonda could have been contributed by industrial effluents and indiscriminate disposal of domestic or sewages directed to the stream of Ngerengere, which are untreated or partially treated [16]. At Towelo, where there are no industrial activities apart from horticultural activities, the concentration of $\mathrm{Cu}$ could have been contributed by the nature of rocks, fertilizer, atmospheric deposition and other sources [22]

The concentrations of $\mathrm{Cu}$ in soils from the respective locations ranged between $0.08 \mu \mathrm{g} / \mathrm{g}-\mathrm{dw}$ at Mgeta and 1.5 $\mu \mathrm{g} / \mathrm{g}-\mathrm{dw}$ at Towelo. All $\mathrm{Cu}$ levels were below TZS [25] permissible limit of $200 \mu \mathrm{g} / \mathrm{g}$. The mildly acidic to nearly neutral $\mathrm{pH}$ values of soil (5.65-7.21) could have contributed to the heavy metals uptake of vegetables from the soil at Kihonda and Towelo. The mean concentration was $(0.436 \pm 0.28)$. Unpaired t-test of the concentration of $\mathrm{Cu}$ in vegetables, tomatoes and soils indicated no significant differences $(t$ $=1.15, \mathrm{P}=0.269$ ).

Similar studies [16, 27, 31, 32] recorded the concentration of copper below permissible limit in cabbages, carrots and tomatoes. With exception of onions at Kihonda $(7.19 \mu \mathrm{g} / \mathrm{g}-\mathrm{dw})$ and carrots at Towelo $(6.11 \mu \mathrm{g} / \mathrm{g}-\mathrm{dw})$, vegetables are safe from $\mathrm{Cu}$ contamination in both areas. The availability of $\mathrm{Cu}^{2+}$ in soil is linked with soil pH. Malik et al. [33] has found that increased soil $\mathrm{pH}$ may also reduce the availability of $\mathrm{Cu}^{2+}$ to vegetables through increased adsorption at cation exchange sites.

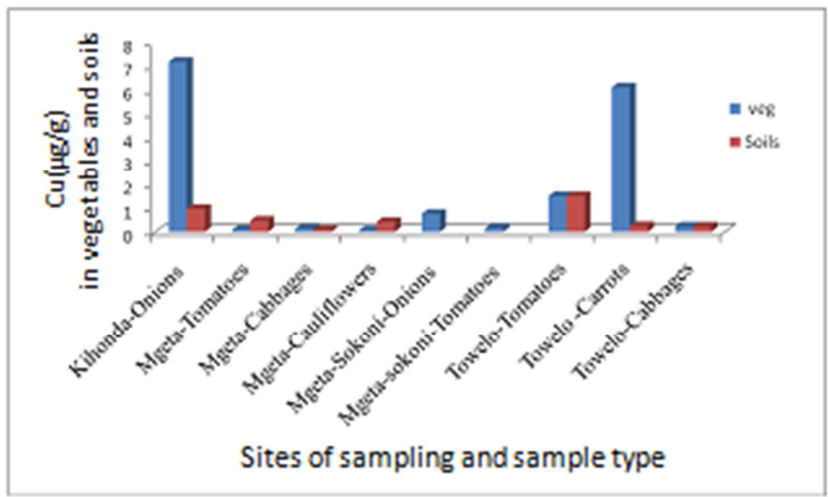

Figure 2. Copper levels in vegetables and soils from Morogoro.

\subsubsection{Chromium}

The concentration of $\mathrm{Cr}$ in vegetables and tomatoes ranged between $(0.38 \mu \mathrm{g} / \mathrm{g}-\mathrm{dw})$ in cabbages at Mgeta and (20.40 $\mu \mathrm{g} / \mathrm{g}-\mathrm{dw}$ ) in onion at Kihonda (Fig. 3). The results were above the FAO/WHO [30] permissible limit $(0.06 \mu \mathrm{g} / \mathrm{g})$. Health effects of consuming $\mathrm{Cr}$ contaminated vegetables include kidney and liver damage, skin rashes, stomach upset and ulcer, respiratory problems and lung cancer and alteration of genetic materials. The mean concentration of $\mathrm{Cr}$ in vegetables and tomatoes was $4.42 \pm 6.71 \mu \mathrm{g} / \mathrm{g}-\mathrm{dw}$.

The respective soils recorded $\mathrm{Cr}$ between $(0.07 \mu \mathrm{g} / \mathrm{g}-\mathrm{dw})$ and $(0.53 \mu \mathrm{g} / \mathrm{g}-\mathrm{dw})$, all values being below TZS [25] permissible limit of $100 \mu \mathrm{g} / \mathrm{g}$. The mean concentration recorded as $0.193 \pm 0.185 \mu \mathrm{g} / \mathrm{g}-\mathrm{dw}$ and unpaired t-test indicated the concentration in vegetables, tomatoes and soil was statistically not showing significant differences $(t=0.291$, $\mathrm{P}=0.774$ ). BCF ratio recorded above 1 , indicating the uptake of heavy metals to vegetables [19]. Variation of soil $\mathrm{pH}$ between mildly acidic ( $\mathrm{pH} 5.53)$ and moderately alkaline $(\mathrm{pH}$ 7.22) could have facilitated $\mathrm{Cr}$ solubility and availability for absorption by vegetables $[19,34]$.

Similar studies by Alamin et al. [35] indicated higher $\mathrm{Cr}$ concentrations in cabbages (1.39 ug/g-dw). Ray et al. [28] studies in non-polluted areas recorded $\mathrm{Cr}(0.03 \mu \mathrm{g} / \mathrm{g}-\mathrm{dw})$ in cauliflower and $(2.45 \mu \mathrm{g} / \mathrm{g}-\mathrm{dw})$ in cabbage with respective concentration in soil of cauliflowers $(0.016 \mu \mathrm{g} / \mathrm{g}-\mathrm{dw})$ and cabbages $(2.947 \mu \mathrm{g} / \mathrm{g}-\mathrm{dw})$.

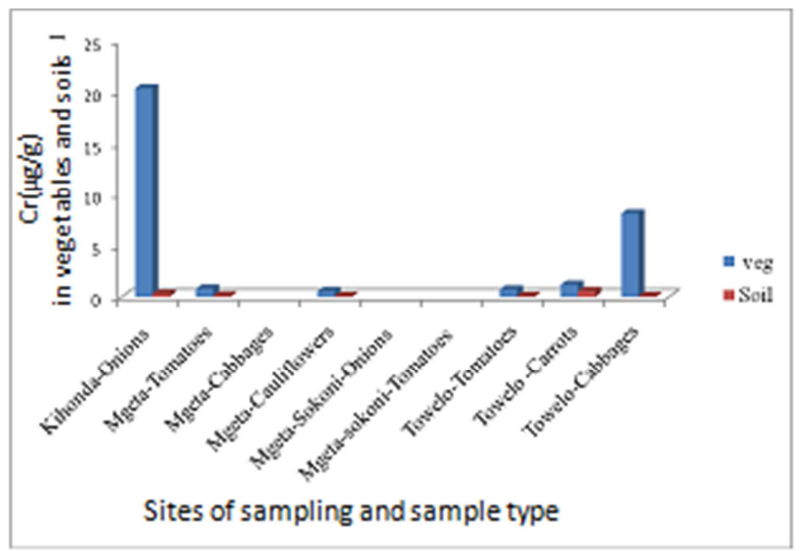

Figure 3. Chromium levels in vegetables and soils from Morogoro.

\subsubsection{Lead}

The concentration of $\mathrm{Pb}$ ranged between non-detectable limit in tomatoes, cabbages, and cauliflowers at Mgeta and (18.17 $\mu \mathrm{g} / \mathrm{g}-\mathrm{dw}$ ) in tomatoes at Mgeta sokoni (Fig. 4). The mean concentration for these vegetables and tomatoes being $6.20 \pm$ $7.05 \mu \mathrm{g} / \mathrm{g}-\mathrm{dw}$. With exception of the non-detectable limits of $\mathrm{Pb}$ in some vegetables and tomatoes which are safe for consumption, all the other concentrations recorded for $\mathrm{Pb}$ were above FAO/WHO [30] permissible limit (0.3 $\mu \mathrm{g} / \mathrm{g})$. Consumption of these vegetables would certainly result in health problems such as cognitive dysfunction, neurobehavioral disorders, hypertension and renal impairment [36]

High levels of $\mathrm{Pb}(7.19 \mu \mathrm{g} / \mathrm{g}-\mathrm{dw}$ and $18.17 \mu \mathrm{g} / \mathrm{g}-\mathrm{dw})$ at Mgeta sokoni in vegetables and tomatoes could be contributed by high traffic of vehicles loading vegetables to Dar es Salaam and other regions. Most of vegetables marketed outside Morogoro, are loaded at Mgeta sokoni.

In the respective soils levels of $\mathrm{Pb}$ were below detection 
limit in all locations except at Towelo $(1.16 \mu \mathrm{g} / \mathrm{g}-\mathrm{dw})$ and at Mgeta $(0.16 \mu \mathrm{g} / \mathrm{g}-\mathrm{dw})$, values which are below TZS [25] permissible limit $(200 \mu \mathrm{g} / \mathrm{g})$.

A study by Al-Chaarani et al. [21] reported $\mathrm{Pb}$ concentrations in vegetables ranged from non-detectable to $2.695 \mu \mathrm{g} / \mathrm{g}-\mathrm{dw}$ while the concentration of $\mathrm{Pb}$ reported by Naser et al. [6] in cauliflower ranged between 1.027 and $1.968 \mu \mathrm{g} / \mathrm{g}$-dw (tomatoes) and between 0.486 and $1.119 \mu \mathrm{g} / \mathrm{g}-\mathrm{dw}$ (cauliflower). Moreover, Bhutto et al. [26] reported that $\mathrm{Pb}$ concentration in onions was $0.022 \mu \mathrm{g} / \mathrm{g}-\mathrm{dw}$ and in cabbages, cauliflowers and tomatoes ranged from $(0.009 \mu \mathrm{g} / \mathrm{g}-\mathrm{dw})$ to $(0.084 \mu \mathrm{g} / \mathrm{g}-\mathrm{dw})$. Similarly, Ray et al. [28] recorded the range of $\mathrm{Pb}$ concentration from $(0.08 \mu \mathrm{g} / \mathrm{g}-\mathrm{dw})$ to $(5.51 \mu \mathrm{g} / \mathrm{g}-\mathrm{dw})$ in cauliflower, cabbage and tomatoes. The respective $\mathrm{Pb}$ concentration in soil was between $(0.74 \mu \mathrm{g} / \mathrm{g}-\mathrm{dw})$ and $(3.88 \mu \mathrm{g} / \mathrm{g}-\mathrm{dw}) . \mathrm{Pb}$ levels measured in vegetables and tomatoes in this study were higher than the above reported values. These values can easily add up to exceed the maximum allowable values especially in the case of children. This becomes even more pronounced knowing that food is not the only source of $\mathrm{Pb}$ intake into the human body [24]. The soil $\mathrm{pH}$ recorded (mildly acidic to mild alkaline) contributed to increasing heavy metal solubility and uptake into vegetables and tomatoes.

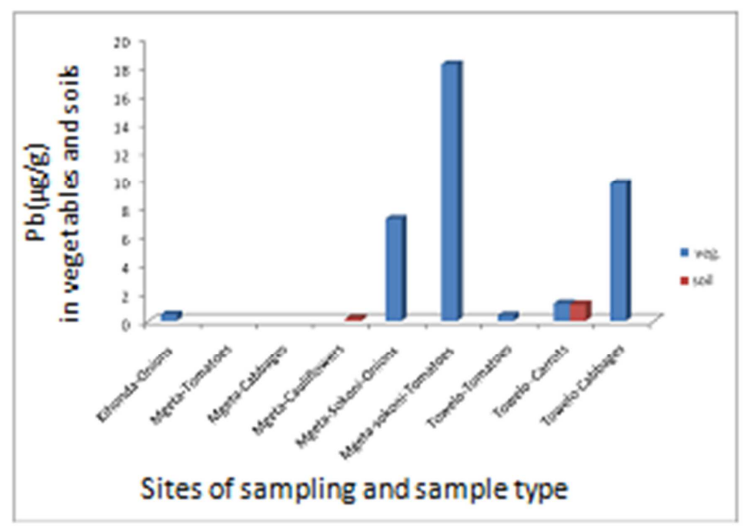

Figure 4. Lead concentrations in vegetables and soils from Morogoro

\subsubsection{Zinc}

$\mathrm{Zn}$ is the least toxic among all heavy metals, and is an essential element in the human diet as it is required to maintain the proper functioning of the immune system, normal brain activity and is fundamental in the growth and development of the foetus. Excessive $\mathrm{Zn}$ in the diet e.g. prolonged daily intake of zinc ranging at $150-450 \mathrm{mg} /$ day is also detrimental to human health [37].

In the present study, $\mathrm{Zn}$ was recorded high in onions, tomatoes, cabbages and cauliflowers. It ranged between 27.40 and $106 \mu \mathrm{g} / \mathrm{g}-\mathrm{dw}$ (Fig. 5) values which were above the FAO/WHO [30] permissible limit of $5 \mu \mathrm{g} / \mathrm{g}$. The mean concentration recorded was $(51.90 \pm 25.40 \mu \mathrm{g} / \mathrm{g}-\mathrm{dw})$. Similar studies [27, 32] also reported levels of $\mathrm{Zn}$ in onions, carrots, cabbages, and tomatoes above permissible levels of FAO/WHO.

The soil samples recorded $\mathrm{Zn}$ levels between $(1.38 \mu \mathrm{g} / \mathrm{g}$-dw) and $(24.80 \mu \mathrm{g} / \mathrm{g}-\mathrm{dw})$, that were lower than in the respective vegetables and lower than the TZS [25] limit. The mean concentration recorded was $7.59 \pm 8.81 \mu \mathrm{g} / \mathrm{g}$-dw. Unpaired t-test indicated statistically significant differences of $\mathrm{Zn}$ in vegetables, tomatoes and soil $(\mathrm{t}=4.39, \mathrm{P}=0.001)$. Since there was no major industry existing in the study areas, it was assumed that the sources of $\mathrm{Zn}$ were probably from motor vehicle tire rubber exacerbated by poor road surfaces and the lubricating oils in which $\mathrm{Zn}$ is found as part of many additives such as zinc dithiophosphates [38].

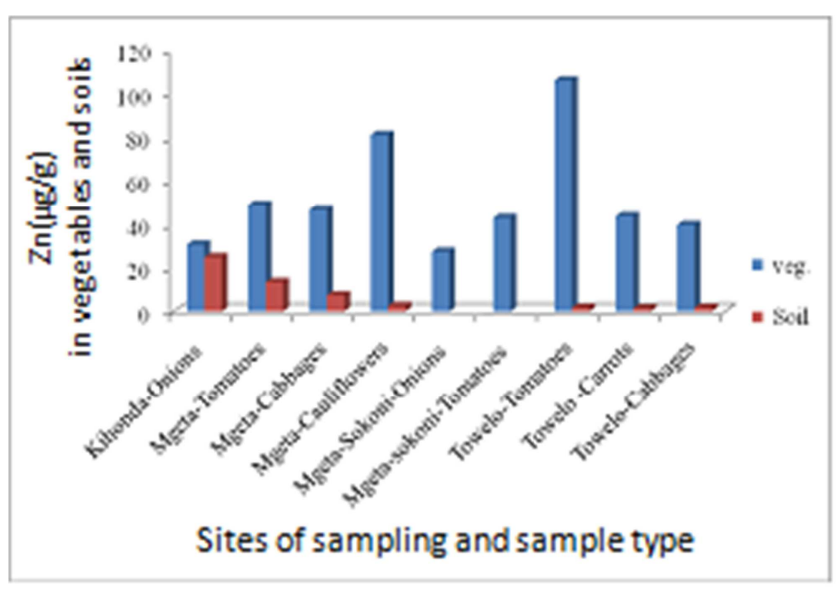

Figure 5. Zinc levels in vegetables and soils from Morogoro.

\subsection{Bioconcentration Factors (BCF) of Heavy Metals}

The BCF of above 1.0 indicates higher uptake of heavy metals in vegetables than in the soil. An area which recorded $\mathrm{BCF}$ below 1.0 indicates high heavy metals concentration in soil in relation to vegetables and therefore low uptake of heavy metals to vegetables [39]. The calculated BCFs for the heavy metals in Morogoro region are presented in Table 2. The BCFs of $\mathrm{Cd}, \mathrm{Cu}, \mathrm{Cd}, \mathrm{Pb}$ and $\mathrm{Zn}$ for all vegetables and at all locations were found to be, in general, above one (1.0) except for $\mathrm{Cu}$ which recorded one (1.0) for tomatoes and cabbage at Towelo and below one $(<1.0)$ for tomatoes and cauliflowers from Mgeta. Cd (onions) at Mgeta as well recorded below one $(<1.0)$. Such high BCF values suggest that these leafy vegetables and tomatoes should not be eaten raw.

The overall BCF observation of heavy metals showed that $\mathrm{BCF}$ values of $\mathrm{Cr}$ and $\mathrm{Zn}$ were the highest as compared to $\mathrm{Cu}$, $\mathrm{Cd}$ and $\mathrm{Pb}$ values from all locations.

Table 2. Bioconcentration Factor (BCF) for samples from Morogoro.

\begin{tabular}{lllllll}
\hline \multirow{2}{*}{ Location (vegetables) } & \multicolumn{9}{l}{ BCF for heavy metals } & \multirow{2}{*}{ Pb } \\
\cline { 2 - 5 } & $\mathbf{C u}$ & $\mathbf{C r}$ & $\mathbf{Z n}$ & $\mathbf{C d}$ & \\
\hline Kihonda (Onions) & 7.41 & 70.4 & 1.23 & & $*$ \\
Mgeta (Tomatoes) & 0.19 & 6.50 & 3.64 & 0.043 & $*$ \\
Mgeta (Cabbages) & 1.75 & 6.75 & 6.28 & $*$ & $*$ \\
Mgeta (Cauliflowers) & 0.43 & $*$ & 31.94 & $*$ & $*$ \\
Mgeta sokoni (Onions) & $* *$ & $* *$ & $* *$ & $* *$ & $* *$ \\
Mgeta sokoni (Tomatoes) & $* *$ & $* *$ & $* *$ & $* *$ & $* *$ \\
Towelo (Tomatoes) & 1 & 10.14 & 61.63 & $*$ & $*$ \\
Towelo (Cabbages) & 24.44 & 2.21 & 31.73 & $*$ & 1.06 \\
Towelo (Cabbages) & 1 & 116 & 23.06 & $*$ & $*$ \\
\hline
\end{tabular}

* Soil/vegetable ratio was not calculated, one of the results was below detection limit

** Areas where soil was not sampled. 


\section{Conclusion}

The results reported in the present study show that concentration of heavy metals $\mathrm{Cd}, \mathrm{Cu}, \mathrm{Cr}, \mathrm{Pb}$ and $\mathrm{Zn}$ in the soil from all nine locations were recorded as below the TZS [25] permissible limits for these metals. The results also indicate that levels of these heavy metals in vegetables and tomatoes varied from below detection limits to well above of the FAO/WHO permissible limits in foods [30]. The mean concentrations of these heavy metals (except $\mathrm{Cu}$ ) in vegetables and tomatoes were also observed to be above the FAO/WHO limits [30] and were therefore concluded as not safe for human consumption. $\mathrm{Cu}$ was the only heavy metal detected at levels allowable for human consumption. $\mathrm{Zn}$ was present at the highest concentration as compared to the other metals. Although most of the studied area had no industries, it was statistically observed that there was significant difference for $\mathrm{Zn}$ content between the studied vegetables and soils. The heavy metals recorded levels above the FAO/WHO permissible limits in vegetables and tomatoes [30] and below the TZS permissible limits in soil [25].

The $\mathrm{BCF}$ for $\mathrm{Cr}, \mathrm{Pb}, \mathrm{Cd}, \mathrm{Cu}$ and $\mathrm{Zn}$ in studied vegetables and tomatoes except for $\mathrm{Cd}$ (onions) at Kihonda and $\mathrm{Cu}$ (tomatoes and Cauliflowers) at Mgeta, were found to be above 1 indicating high uptake of heavy metals in the vegetables and tomatoes from the soil. Two sites at Towelo for $\mathrm{Cu}$ (tomatoes and cabbages) had BCF lower than 1 indicating that $\mathrm{Cu}$ was in balanced proportions between the soil and the vegetables. Overall results suggest that vegetables and tomatoes grown within the study area might place the consumer at health risk, therefore they are not safe for consumption in their raw state.

\section{References}

[1] Noor-ul, A. and Tauseef A., Contamination of soil with heavy metals from industrial effluent and their translocation in green vegetables of Peshawar, Pakistan RSC Advances, 5, 2015, p. 14322-14329.

[2] Bassey, F. I., Iwegbue, C. M. A., Obi-Iyeke, G. E., Tesi, G. O., Rotu, A. R., Gobe, O. A. and Tsafe A. I., Heavy metals in soils and tomatoes grown in urban fringe environment in Asaba, Delta State, Nigeria. Nigerian Journal of Basic and Applied Science, 22(1\&2), 2014, p. 27-31.

[3] Colak, H., Soylak, M. and Turkoglu, O., Determination of trace metal content of various herbal and fruit teas produced and marketed from Turkey. Trace. Elem. Electrolytes. 22, 2005, 192-195.

[4] Oktem, F., Yavrucuoglu, H., Turedi, A. and Tunc, B., The effect of nutritional habits on hematological parameters and trace elements in children. SuleymanDemirel Univ. Tip Fak.Der. 12, 2005, p. 6-10. (In Turk1sh).

[5] Manohara, B. and Belagali, S.L., Characterization of essential nutrients and heavy metals during municipal solid aste composting. International Journal of Innovative Research in Science, Engineering and Technology, 3 (2), 2014, p. 9664-9672.

[6] Naser H. M., Shil, N. C., Mahmud, N. U., Rashid, M. H. and Hossain, K. M., Lead, cadmium and nickel contents of vegetables grown in industrially polluted and non-polluted areas of Bangladesh. Bangladesh J. Agril. Res. 34(4), 2009, p. $545-554$.

[7] Taghipour, H. and Mosaferi, M., Heavy metals in the vegetables collected from production sites. Health Promotion Perspective. 3(2), 2013, p. 185-193.

[8] Siddiqui, M. F., Cadmium induced renal toxicity in male rats. Journal of Medicine, 15, 2010, p. 93-96.

[9] Ministry of Agriculture and Food Security. Horticulture development in Tanzania 2002, Ministry of Agriculture, Tanzania.

[10] De Putter, H., Van K, M. J. and De V, C. L. M., Overview of the vegetable sector in Tanzania, Report No.1. 2007.

[11] Kibassa, D., Kimaro, A. A. and Shemdoe, R. S., Heavy metals concentrations in selected areas used for urban agriculture in Dar es Salaam, Tanzania. Scientific Research and Essays, Vol. 8(27), 2013, p. 1296-1303.

[12] Othman, O. C., Heavy metals in green vegetables and soils from vegetable gardens in Dar es Salaam, Tanzania. Tanz. J. Sci. 27, 2001, p. 37-48.

[13] Amour, K. O., Assessment of heavy metal concentrations in soil and green vegetables (vigna unguiculata) around the volcanic mountain of Oldoinyo lengai in Ngorongoro district Arusha, Tanzania. 2014, MSc (Physics) Dissertation, University of Dar es Salaam.

[14] Kilimia, F. Z. K., A comparative study of heavy metal pollutant levels in vegetables grown under urban and rural conditions in Dar es salaam, Tanzania. 2001, MSc (Chemistry) Dissertation, University of Dar es Salaam, Chemistry Department.

[15] Mwijage, E. F., Mobilization of selected chemical constituents into the human chain via horticultural produce grown in Dar es Salaam. 2002, MSc (Chemistry) Thesis, University of Dar es salaam, Chemistry Department.

[16] Chove, B. E., Ballegu, W. R. and Chove, L. M., Copper and lead levels in two popular leafy vegetables grown around Morogoro Municipality, Tanzania. Tanz. Health Res. Bull. 8, 2006, p. 1.

[17] Lugwisha, E. H., and Othman, C. O., Levels of selected heavy metals in soil, tomatoes and selected vegetables from Lushoto District-Tanzania. International Journal of Environmental Monitoring and Analysis 2(6), 2014, p 313-319.

[18] Kibassa, D., Kimaro, A. A. and Shemdoe, R. S., Heavy metals concentrations in selected areas used for urban agriculture in Dar es Salaam, Tanzania. Sci. Res. Essays. 8(27), 2013, p. 1296-1303.

[19] Akinola, M. O., Njoku, K. L. and Ekeifo, B. E., Determination of lead, cadmium and chromium in the tissue of an economically important plant grown around a textile industry at Ibeshe, Ikorodu Area of Lagos State, Nigeria. Advances in Environmental Biology, 2, 2008, p. 25-30.

[20] Kothari, C. R., Research methodology, method and techniques. 2nd Edn, 2004. New age International (P) Ltd, New Delhi Vikas, India.

[21] Al-Chaarani, N., El-Nakat, J. H., Obeid, P. J. and Aouad S., Measurement of levels of heavy metal contamination in vegetables grown and sold in selected areas in Lebanon. Jordan J. of Chem. 4, 2009, p. 303-315. 
[22] WHO 2007 Joint WHO/Convention Task Force on the Health Aspects of Air Pollution, Health risks of heavy metals from long-range trans-boundary air pollution, 2007, World Health Organization, Geneva.

[23] FAO/WHO, CODEX ALIMENTARIUS International Food Standards CODEX STAN-193. Codex Alimentariuscommission, WHO/FAO, 1995.

[24] Oti, W. J. O. and Nwabue, F. I., Heavy metals effect due to contamination of vegetables from Enyigba lead mine in Ebonyi state, Nigeria. Environment and Pollution, 2(1), 2013, p. 19-26.

[25] TZS 972:2007 Soil quality - Limits for soil contaminants in habitat and agriculture. 2007, Tanzania Bureau of Standards (TBS), Dar es Salaam.

[26] Bhutto, R., Abbas, M., Parveen, Z., Iqbal, M., Iqbal, S. and Ahmed, M., Monitoring of toxic metals (cadmium, lead, arsenic and mercury) in vegetables of Sindh, Pakistan. Kathmandu University Journal of Science, Engineering and Technology, 6, 2010, p. 60-65.

[27] Kirmani, M. Z., Sheikh, M., Farah, N., Iftikhar, I. N. and Erum, Z., Determination of some toxic and essential trace metals in some medicinal and edible plants of Karachi city. Journal of Basic and Applied Sciences. 7, 2011, p. 89-95.

[28] Ray, L., Banerjee, D., Bairagi, H., Mukhopadhyay, S., Pal, A. and Bera, D., Heavy metal contamination in fruits and vegetables in two districts of West Bengal, India. Electronic J. Environ. and Agriculture Food Chemistry. 9, 2010, p. 1423-1432.

[29] Sobukola, O. P., Adeniran, O. M., Odedairo, A. A. and Kajihausa, O. E., Heavy metal levels of some fruits and leafy vegetables from selected markets in Lagos, Nigeria. African J. Food Sci. 4, 2010, p. 389-393.

[30] FAO/WHO, CODEX ALIMENTARIUS International Food Standards CODEX STAN-179. Codex Alimentarius commission, WHO/FAO, 2003.
[31] Farooq, M., Farooq, A. and Rashid, U., Appraisal of heavy metal contents in different vegetables grown in the vicinity of an industrial area. Pakistan. J. Bot 40, 2008, p. 2099-2106.

[32] Bosiacki, M. and Tyksiñski, W., Lead, zinc, iron and manganese content in edible parts of some fresh vegetables sold on markets in Pozincañ. Journal of Elementol, 14, 2009, p. 13-22.

[33] Malik, R. N., Husain, S. Z., and Nazir, I., Heavy metal contamination and accumulation in soil and wild plant species from industrial area of Islamabad. Pakistan J. of Bot. 42(1), 2010, p. 291-301.

[34] Akan, J. C., Abdulrahman, F. I., Sodipo, O. A., and Lange, A. G., Physicochemical parameters in soil and vegetable samples from Gongulon agricopperltural site, Maiduguri, Borno state, Nigeria. Journal of American Science, 6, 2010, p. 7-12.

[35] Alamin, M. B., Mhapes, A. A., Bejey, A. M., Sade, A., Atweer, R. H., Dubali, K. and Saad, D. M., Determination of essential and toxic elements in Libyan foodstuff using instrumental neutron activation analysis (INAA). Journal of Radioanalytical and Nuclear Chemistry, 271, 2007, p. 247-250.

[36] Patrick, L. N. D., Lead toxicity part ii: The role of free radical damage and the use of antioxidants in the pathology and treatment of lead toxicity. Alternative Med Rev. 11, 2006, p. 114-127.

[37] Johnson, A. R., Munoz, A., Gottlieb, J. L. and Jarrard, D. F., High dose zinc increases hospital admissions due to genitourinary complications. J Urol. 177, 2007, p. 639-643.

[38] Qasem, M., Kamal, A. and Moman, I., Contamination of roadside soil, plants, and air with heavy metals in Jordan, A comparative Study. Turk J. Chem. 23, 1999, p. 209-220.

[39] Solecki, J. and Chibowski, S., Determination of transfer factors for $137 \mathrm{Cs}$ and $90 \mathrm{Sr}$ isotopes in soil-plant system. Journal of Radioanalytical and Nuclear Chemistry. 252, 2002, p. 89-93. 